\title{
MASCULINITY, MIGRATION, AND FORCED CONSCRIPTION IN THE SYRIAN WAR
}

\author{
KRISTIN V. MONROE \\ University of Kentucky \\ (iD https:/ / orcid.org/0000-0002-4759-5027
}

In June 2015, Rami was a recent university graduate in finance working in a bank in Damascus. While a student, he had received an exemption from military service. But his student days now lay behind him, the war was on, and he was due to report for service in September. He did not have the money to re-enroll and continue in school for his master's degree. News about the possibility of getting a visa to Qatar came from neighbors. "I had to accept," he explained:

I couldn't wait. I had to leave. When I was a student, I worked in a restaurant one or two days a week - just to pay for things. But not even in my worst dreams did I imagine myself ever working in a restaurant [after finishing school]. I studied for years, I was one of the best in my class. And now, I'm not even a captain waiter. I'm a shisha boy. ${ }^{1}$

Rami's escape from military duty in wartime Syria to Doha, Qatar, where he worked at a high-end "Oriental" restaurant involved the exchange of one form of service for another. His telling of this exchange offered the understanding that his labor migration was a move imposed by the war, a development that entailed 
not only a fall in status but also an upending of who he had been and who he had imagined he would become.

Rami's blunt and plaintive "I'm a shisha boy" was one of the many moments in my conversations with Syrian men living and working in Doha that cut through the ways we commonly think about the long war in Syria. The Syrian war is an ongoing conflict fought between the Syrian regime, the regime's domestic and foreign supporters, and the many domestic and foreign forces that oppose it. It developed, in 2011, from discontent with the regime's violent suppression of civil uprisings that formed part of the broader Arab Spring protests. Much of our understanding of the war's impact focuses on the experiences of Syrians displaced by violence and the untold forms of suffering they have endured both before and since leaving their country for highly precarious lives and futures in places within and far beyond the region (see, e.g., Maadad and Rodwell 2016; Baban, Ilcan, and Rygiel 2017; Naguib 2017; Pearlman 2017). The group of men I interviewed in Doha in 2017-2018 differ from this population. They are not refugees and do not identify as displaced. They carry Syrian passports, make periodic visits to Syria to see their families, and plan to return to their home country in the future. Yet the war has not only compelled their labor migration or prolonged it but centrally organizes their lives and movements. In this essay I therefore provide a different and critical perspective on the conflict by examining how the war's reach can be located as well amid the losses, interruptions, and experiences of those Syrians who have until now largely escaped its incredible violence. By looking closely at how the war has altered the life trajectories of and produced distinct modes of vulnerability for military-age men, I develop an argument about how, although they avoid fighting by going to work in Qatar, the lives of a group of Syrian men remain defined by conscription.

Through my investigation of how these men are located in a landscape of conscription that extends beyond the borders of Syria and into their lives as workers in Qatar, I build on anthropological knowledge of how masculinity is shaped by and through contexts of political destabilization (Pankhurst 2008; Hafez 2012; Aciksoz 2017). I demonstrate how the Syrian conflict has both altered and upheld the relationship between men and the nation-state. In fulfilling their masculine role as providers for and protectors of their families, military-age men have avoided becoming soldiers and embarked on new migration itineraries. Yet these migrations, which enable men to buy themselves out of their state-prescribed military duty as male citizens, have also led to circumscribed lives in the highly policed labor system of the Arab Gulf. 
In examining how forced conscription has come to define the lives of a group of Syrian men, I join other scholars (Allsopp 2017; Turner 2017, 2019; Suerbaum 2018a, 2018b) committed to developing a gendered and intersectional approach to the study of the Syrian conflict that investigates the complexities of masculine identity and ascription for both those who have stayed and those who have left. I contribute to understandings of the socially transformative conditions of war (Lubkemann 2008) by tracing, across two authoritarian regimes, the trajectories of migration and manhood (Ghannam 2013) undertaken by a group of Syrian men during a time of conflict. Rather than tracing war's destruction, I offer insights into its stages of remaking by showing how these men navigate a wartime landscape to establish livelihoods that enable them to prepare and plan for the near and farther-out future.

In Baathist Syria, citizenship has been measured, as Rahaf Aldoughli (2018) writes, "by men's readiness to die for the nation and a commitment to a masculinist conception of national membership based on militarism and chivalry." A certain kind of patriarchal bargain (Kandiyoti 1988), not unlike the one Sherine Hafez (2012) describes being struck by both women and men in Mubarak-era Egypt, has characterized the nation-building and citizen-making processes of the Republic of Syria since it emerged as an independent state following the Second World War. In this bargain, the authoritative and patriarchal father, personified by the former and current presidents (Hafez al-Assad and Bashar al-Assad, a father-and-son pair that have ruled since 1971), offers protection for the Syrian people as the country has been at war with one or more foreign enemies since the establishment of Israel in 1948. Until a more recent neoliberal turn (Wedeen 2013), a range of welfare-state provisions included subsidies on commodities such as bread, rice, and sugar, as well as diesel and chemical fertilizer, on which especially rural Syrians depended (De Châtel 2014). In return, the regime demands the loyalty and public support of all citizens, whose efforts are in fact necessary to maintain this safety and security; citizens, for example, are expected to surveil one another and inform the authorities of acts of disloyalty, and men of military age are dutifully to report for mandatory military service.

However, as suggested by the number of men who have avoided military service, with estimates at tens of thousands between 2011 and 2016 (Khaddour 2016) — including those who become refugees, hide out within Syria's borders (Al-Jablawi 2019) or, like those I discuss in this essay, find jobs outside of Syria to work toward a payment that exempts them from duty - the current war has unsettled some of the terms of this patriarchal bargain. Naturally, given the risk 
of death, being a soldier during wartime appears generally undesirable. But the civil dimensions of the Syrian conflict make for an important reason that so many Syrians would want to avoid becoming a soldier for the Assad regime, as this has meant not only fighting foreign enemies but also killing, brutalizing, and destroying the homes of Syrians. Being a regime soldier, in short, has meant having to wage war against Syrian children, women, and men. Whether or not a man politically supports the regime, awareness of this fact has served as a strong deterrent to doing what has been framed as one's duty as a male citizen-soldier.

But men risk conscription not only by the state. As men, they have been defined throughout the war as potential combatants both by the regime/its supporters and by the myriad armed groups that have comprised its opponents (Davis, Taylor, and Murphy 2014). Quite simply, if you are not on one side, you have been construed as a member of an enemy side. Fear of conscription by one or another faction has therefore become a way of life for military-age men, always already imagined as soldiers. For the men whose stories I explore here, this situation has created certain vulnerabilities and disrupted their "masculine trajectories" (Ghannam 2013) — the process of becoming a man across the life course — as working in Qatar has meant deferring future plans to labor to pay off the state for freedom and access to home.

I begin the essay by discussing the broader context of migrant labor in Qatar and how it connects with the politics of positionality that shaped the situated terms of my own research with Syrian men living and working in Doha. Based on their experiences, I then examine how the persistent possibility of wartime conscription in Syria shapes the lives of Syrian men working overseas. Next, I show how, in avoiding becoming soldiers, these men in fact become enlisted in another form of service in which their lives are not really their own. I argue that, to provide for their families, these men cast off the patriarchal bargain of old that demanded the fulfillment of one's duty as a citizen-soldier and enter into a new bargain with the state that requires their conscription in the global capitalist labor force. The patriarchal bargain is not displaced so much as its terms are altered as it extends out into a transnational capitalist landscape. These men offer a "different kind of war story" (Nordstrom 1997), one that centers not on the violence of war but on the gendered vulnerabilities of wartime existence and the life projects it shapes in relation to the negotiation of masculinities. 


\section{WORK AND RESEARCH IN QATAR}

Qatar is a small, wealthy, oil-producing Persian Gulf nation enormously rich in natural gas reserves, with a population of nearly three million, more than 80 percent of whom are (primarily male) foreign resident workers from across the globe (Khatri 2017). In the midst of the country's regional and global rise-from its expanding role in the region's geopolitics and pursuit of a higher global profile in the realms of architecture, tourism, and international sporting - the population has increased by 40 percent since 2010, and the vast majority of people live in and around the capital city of Doha (Al-Monitor 2017).

Although Qatar is the Gulf Cooperation Council (GCC) country with the highest number of non-nationals, ${ }^{2}$ estimates from the European University Institute's Gulf Research Centre website demonstrate the unique "migrant-majority" demographics of many other Gulf societies as well. ${ }^{3}$ Given this fact, anthropological investigations undertaken in GCC countries have largely focused on non-national residents. Two groups have served as the primary locus of inquiry: Asian and African workers at the bottom of the labor hierarchy employed in the construction, transportation, domestic, cleaning, and sex-work trades (e.g., Nagy 1998; Gardner 2010; Mahdavi 2011; Gardner et al. 2013; Ahmad 2017; Gardner 2018), and much higher-status expatriate members of the business and professional communities (e.g., Vora 2013, 2018). While these studies have enabled us to see how non-nationals such as members of the South Asian diaspora cut across these two tiers (Leonard 2003), less attention has been given to laborers working in front-ofhouse jobs in hospitality, security, retail, and daycare.

A crucial dimension to understanding life for the foreign workers in GCC countries is the kefala, or sponsorship, system that undergirds the labor structure and produces "hierarchized differences between citizens and noncitizens particularly by ensuring the impermanence of the region's noncitizens" (Ahmad 2017, 31). With limited paths to naturalization, this system treats all foreigners as "impossible citizens" (Vora 2013), constituted as contracted, temporary resident-workers requiring an in-country sponsor. Sponsors hold substantial control over workers as the latter require their employers' approval, for example, to change jobs and, until 2018, to exit the country. Yet the sponsorship system is not one size fits all, and higher professional status, as I learned through my own experience as a visiting scholar at a university in Qatar, translates into more autonomy. Since 2010, after winning the bid to host the 2022 World Cup, Qatar's labor laws and conditions, particularly those that concern the highly disenfranchised workers building the transportation and stadium infrastructure, have come under intensified scrutiny 
by human rights organizations, journalists, documentary filmmakers, and academics. As a result, the government has introduced some reforms (Qatar Government Communication Office on Labour Reform), and in 2017, the International Labour Organization (ILO) opened an office in Doha and entered into a three-year "technical cooperation programme to carry out extensive labour reforms focusing on wage levels and payment, reform of the sponsorship system, and the promotion of workers' voice [sic]" (ILO n.d.).

The lives of Syrian men in Qatar can reveal something of the heterogeneity of the sponsorship system and the inadequacy of describing it solely through the migration experiences of the "quintessential low-paid construction worker in the Gulf" (Vora and Koch 2015, 545). Low-paid male workers in the construction and cleaning industries generally live in crowded if not substandard housing conditions in labor camps on the peripheries of cities (Babar and Gardner 2016), are often recruited and exploited by so-called middleman brokers and agencies in their home countries (Jureidini 2014), and regularly find employment with agencies who then subcontract their labor to employers for various periods of time (Gardner 2018).

By contrast, the Syrian men I met lived in modest but adequate employer-provided two-bedroom apartments - two or three per bedroom-in buildings in central Doha. They ranged in age between twenty-eight and forty-five and mostly held jobs in the food service/hospitality industry across two different, multibranch restaurant chains. They obtained their jobs through personal networks and, as Arabic speakers working in service, some even in high-end restaurants that attracted mainly non-Qatari Arab customers alongside Qatari ones, they were engaged in labor much more visible and integrated into the everyday fabric of Doha society. At the same time, like most of the country's lower-level migrant workers, they were subject to the labor structure's restrictions - which make it difficult to change jobs, for example - and to many of its hardships, such as residence-workplace transportation arrangements that could add one to two hours, often on an un-air-conditioned bus or van, onto a ten-to-twelve-hour workday.

Migration flows into the GCC countries are "carefully engineered" through state ministries' policies (Jamal 2015). This engineering has formal and documented dimensions, such as the (pre-arrival) criminal background check and the (in-country) medical test required for all resident workers, as well as more informal undocumented features, like the curtailing of labor migration of certain communities because of their perceived political associations, and the "fitting" of certain nationals with certain types of work (Nagy 1998, 92). For example, African men are funneled into security jobs, Filipina women into daycare, South Asian 
men become drivers. Syrians, like other Arabs, work in a wide range of service and professional-sector jobs and share linguistic — and to some extent, cultural and religious - ties with their Gulf Arab hosts. In responding to the out-migration flows of Syrians over the past eight years, many Gulf states claim that, although they offer no system of asylum for Syrians, they have relaxed their entry and residency laws to allow sizeable numbers (temporarily) to migrate (De Bel-Air 2015). The Syrian men I spoke with saw things differently, citing, for instance, the impossibility of bringing their wives and children to Doha, because "they stopped giving family visas when the war began," as one put it. I found in my conversations with Syrians in Qatar that they do not feel that they have held any special status as Syrians in their migration trajectory. Recent studies corroborate this perspective, finding that the Gulf countries have not been particularly receptive toward Syrian refugees (Valenta and Jakobsen 2016, 646) and that most migrants from Syria arrived before the war began (Valenta and Jakobsen 2017, 45). In fact, because Qatar and other GCC states have been allied together against the Assad regime and served as frontline actors during the war working to dismantle it (Lynch 2018), Syrians find themselves in a precarious position among the Arab worker populations: those who express support for or are suspected of supporting the Assad regime are constituted as a security threat.

The vulnerabilities faced by Syrian and other foreign laborers raise important ethical concerns about conducting ethnographic research with migrant communities in the Gulf region. While the situation is of course relative to the status and social capital of the person in question, formalized conversations between workers and researchers or journalists can put workers at risk of repercussions, from disciplining by their employer to loss of employment followed by deportation, and even to arrest. In this setting, my own positionality helps explain how, as a researcher from the United States, I was able to gain access to a group of Syrian migrant laborers in Qatar and learn about their experiences of labor and migration during the Syrian war.

My scholarly interests in forced conscription during the war in Syria intersect with my personal life. I am married to a Syrian man, a naturalized U.S. citizen who emigrated in 2006 and has returned to Syria twice during wartime following the (not war-related) deaths of two close family members. The threat of conscription hung less over his 2012 visit, in the early days of the war, than it did over a visit in 2016, but, in short, I — through and for him, his brother, his relatives, and neighbors - have faced this fear. Although Syrian law recognizes dual citizenship, "if a person's original citizenship is Syrian, then he is fully liable to the Syrian laws" 
(Syrian Embassy in Australia n.d.). Thus, although he is a U.S. citizen, my husband always has to show his Syrian national identity card when he enters Syria, and as a Syrian male registered in the state system, he remains eligible for conscription. The essentialism of his identity as a Syrian male citizen, in that it overrides his U.S. passport, has been reinforced at other border entries in the Arab world: in Lebanon (where it makes geopolitical sense due to the Syrian conflict's entanglement in matters of Lebanese society and state), but also in Morocco, where in early 2018 a member of the Casablanca airport security forces nearly prevented us from boarding our flight because my husband did not display his Syrian national identity card along with his U.S. passport.

My analysis in this essay draws on interviews conducted in 2017-2018 in a mix of English and Arabic with twelve Syrian men living and working in Doha. ${ }^{4}$ The first men I sat down to speak with formally were two of my husband's distant relatives. Although, as I describe below, they had no interest in participating in my research themselves, they were willing to put me in contact with their coworkers. In a move that secured my respectability in a patriarchal field (cf. Abu-Lughod 1988), while also offering assurance when sharing personal details with a stranger, I was introduced and accompanied by my husband in several of the initial meetings. From these encounters, I would ask for referrals to others who might want to share their stories with me.

To address the question of how my positioning shaped my ethnographic knowledge, I would note first that I held various identities. During some conversations, I felt that I was understood as a partial insider. Being from the United States meant I was surely an outsider for the men I spoke with and, for some, as I discuss later, this proved a problem. But I was also the wife of a Syrian man whose family lives in Syria. This fact communicated to my interlocutors that I knew something about what the war means for Syrians and, quite simply, that I cared. When we hosted men in our apartment for meals, as a middle-aged wife and mother I easily took on the gendered role of attentive listener and hospitable homemaker. In the public, more neutral settings where I met a couple of men on my own while they were on breaks from work, I presented a more professional identity. This duality generated forms of both distance and closeness that characterized the social dynamics of the conversations on which my analysis is based.

However, as Todne Thomas (2016) reminds us, the ethnographic relationship does not comprise just one person. Rather, this relationship is forged through a process of what she calls "negotiated recognition," whereby research participants, too, structure their encounters with the anthropologist/researcher (Thomas 2016, 
81). Readings of solidarity made by participants can create ties of affinity with the researcher. And likewise, readings of difference, though often unspoken, may be projected onto the relationship between researcher and researched and, I found, can sometimes break it off.

Sitting down in our apartment's living room to speak formally about the impact of the war with two brothers, my husband's second cousins (mentioned above) with whom I had spent time casually on numerous occasions, I found their response stony. "Let me tell you about how the U.S. has fueled the war; you don't know about this, do you?" the older of the two started out in anger when I asked my first question. This set the tone, and the younger brother, generally a more laid-back personality, followed his lead. While in our interactions until then I had held the position of distant affine, the way they spoke to me in the frame of the interview foregrounded my identity as a U.S. citizen who implicitly supports - and at the same time remains ignorant of or indifferent to the effects of - U.S. foreign policy and its operations in Syria. The moment evoked both Carolyn Nordstrom's $(1997,5)$ argument about the fiction of the concept of local wars and the imperial character of Western research (Thomas 2016). These men, and perhaps others with whom I spoke, saw the war that has destroyed their country as one in which the world, the United States, and even I were implicated. It was a moment that gave lie to my so-called insiderness and showed how political and historical realities configure the positioned nature of our identities and the nature of anthropological productions themselves (Narayan 1993).

All but one of the men I spoke with hail from the majority-Druze Suweida province whose leaders have had a variable relationship with the Assad regime since the start of the conflict — even openly advising its men to evade conscription at one point (Naylor 2015). ${ }^{5}$ This region has remained under regime control, at least nominally, throughout the war, and its population is often perceived as having a pro-regime stance. Early on while living in Qatar, I learned about a Syrian man living in Doha who had posted pro-Assad comments on his Facebook page. When someone read this and reported him to the police, the man lost his job and was deported. To try and allay the men's vulnerability vis-à-vis the U.S., Qatari, and Syrian security state apparatuses, I trod carefully in my conversations and did not seek to elicit their political opinions. Moreover, in my analysis, I have sought to avoid framings of "for" or "against" the regime. No necessary correspondence (Hall 1985) exists between (inherited) sectarian identity and political position. Indeed, what the stories of these men from the majority-Druze region bring to a broader understanding of the Syrian conflict is the complexity of Syrians' relation- 
ships to the regime. Amid this complexity we discover a much-needed shading of the war that calls into question its simplistic sectarian narratives (Phillips 2016, 48). Important to my analysis is the fact that conscription cuts across sectarian and political identities and raises issues of masculinity, vulnerability, fear, and other personal issues that become more significant than abstract affiliations when people face the pragmatic dangers of war. Having described the labor context and the politics of positionality that shaped my research questions and methods, I turn now to consider how the Syrian conscription regime participates in the making of men.

\section{CONSCRIPTION}

In Assad-era Syria, compulsory military service has proven foundational to the profoundly gendered construction of the Syrian "military-nation" (Altinay 2004) and a "totalizing project by which boys are made into men and citizen-soldiers forged out of the male masses" (Gill 1997, 533). Before the current civil war, most Syrian men did not view military service as a contentious issue; it was simply what every man did (Davis 2016, 51). In the stories told by my husband, his relatives, and our friends, in the prewar period, military service constituted a rite of passage into Syrian citizenship-manhood in ways that go beyond the cultivation of a militarized masculinity through soldierly exercises. For instance, for most Syrian men going to the army meant engaging in new modes of self-care, looking after their clothes' washing or their meals for the first and perhaps only - if a man returns to his natal home or heads into marriage following military service - time in their lives. As Lesley Gill (1997) and Andrew Canessa (2012) have written about indigenous Bolivians, it is also through military service that the national community itself is reimagined as men from around the country are drawn together and meet their co-nationalists with different accents who hail from diverse sectarian and ethnic backgrounds. Some Syrians learn about their Kurdish or Druze fellow citizens for the first time during their military service. Having had their civilian national identity cards confiscated at the start of their service and replaced with military ones, conscripts focus their talk on tasreeh (time of discharge). It was at the moment of their demobilization that conscripts would both get their lives back, signified by the return of their civilian identities, and also begin their lives in the sense of planning for marriage and securing a livelihood.

Before the war, a formalized system of exemptions spared many from military service. Being the only son in a family qualified one for an exemption, as did certain medical issues. Syrians living outside the country could pay a fee in lieu of their service at costs that have varied in the past decade from between US\$500 
and US\$15,000. In the early 2000s, in a move aimed to reduce barriers to Syrian expatriates and their descendants from visiting Syria, the costs of exemption began to be determined according to a complex matrix of factors having to do with where a man was born, at what age he left Syria, for how long he had resided abroad, and where he lived outside Syria (Immigration and Refugee Board of Canada 2014). University students received automatic postponements that could be extended after graduation depending on their employment status or if they were working abroad. Informal pay-for-release arrangements between the high status and well-connected and high-ranking military officials could also reduce a man's length of service, soften its experience, or even dismiss the service requirement altogether. A Syrian man in his late forties whom I met recently in the United States related one example of this. Being Druze, as he told it, he was not as fortunate as many well-connected Alawite (the minority sect of the ruling party in Syria since 1971) men who never serve at all, but his father paid the general in charge of his assigned division to allow him to do a six-month period of boot-camp training and then serve out his remaining time living at home working in a nearby civil service office. The first decade of Bashar al-Assad's presidency also brought with it significant reductions in the length of required military service: from thirty months to twenty-four months in 2005, to twenty-one months in 2008, and to eighteen months in 2011 (Khaddour 2016). The war has changed all of this.

Hamid, a twenty-eight-year old restaurant employee from Lattakia, came to Qatar in 2008. He filed the document (sanat iqama) with the government, indicating that he could not complete his military service owing to his working abroad. At that time, the fee for permanent release from service, to be paid within a fiveyear timeframe, was US\$5,000. (I hear it is now US\$8,000 for those living abroad no less than four years). ${ }^{6}$ He returned home for his first visit in July-August 2011, but, because he has not paid the fee, he cannot return again without facing immediate conscription. In describing his 2011 visit, he provided a snapshot of the early days of a war that began as a civil uprising brutally repressed by the regime:

I went home and it was Ramadan, and at the beginning it was in Deraa, and we weren't thinking that it was coming to other parts of the country. But while I was home there were protests near my building, outside of a mosque. We would watch from our apartment. And then one time it was broken up, there were plainclothes policemen, they had gone into the crowds, they were shooting up in the air, and everyone went running scared. 
Police began to do house-to-house searches looking for those involved or suspected of involvement with the protest movements. Hamid's mother kept asking him to leave the country earlier than he had planned. Fear concerning the gravity of events - and, for his mother, the particular vulnerability of young men to arrest, torture, and disappearance — quickly set in. "She would hide my shoes," Hamid told me. "If I went out and came home, I would not see my shoes by the door." With this action, a quiet domestic moment inlaid with terror, his mother hoped to conceal his presence from the police. Even before the intensification of the conflict, then, before life for Syrians was torn asunder by the violent and politically fragmented landscape of myriad armed groups, tremendous fear ruled the everyday (Pearlman 2016). In my conversations with Syrian men working in Doha, I found that state conscription practices proved central to the workings of this fear.

Throughout the war, the regime has had to rely on a dwindling number of soldiers. Tallies of civilian deaths due to the conflict vary significantly, but the United Nations estimates that more than four hundred thousand have been killed (Specia 2018). Although it is well known that the Syrian forces have faced heavy losses in the more than eight years of fighting, no figures are available for the number of Syrian soldier deaths. Media and policy reports are rife with accounts of men who have fled the country to evade conscription and soldiers who have defected from the army doing the same (Koehler, Ohl, and Albrecht 2016), suggesting a reduction of the prewar numbers of the Syrian army by as much as half (Khlebnikov 2018). Other men of military age have stayed in Syria but moved to areas outside of government control to avoid conscription. Others who live in areas even nominally controlled by the regime have been immobilized. My brother-in-law, for example, restricted his movements to just within his village limits until he reached the age of forty-three (the target age for conscripts is eighteen to forty-two) to avoid major roads with government security checkpoints.

The old rules regarding service exemptions no longer apply. In recent years, as reported by the Immigration and Refugee Board of Canada (2017), the government has continually changed its policies regarding conscription, reserve duty, and postponements. The regime's desperation for soldiers, with the war now in its ninth year, has meant the conscription of some members of the population who used to be exempt, such as university students, a family's only son, and men over the age of forty-two. Amer, a thirty-year-old restaurant worker, related to me how before the war students could postpone military service, but now, if you are the eldest son, for example, and you are enrolled at a university and you have younger brothers, when the next brother reaches the age of eighteen, the government will 
conscript the oldest brother-regardless of whether or not he has finished his studies - and allow the next-oldest brother to "take his place as a university student." In short, a family is allowed only one son of military age to postpone conscription due to his status as a university student. "Is this a straightforward matter of needing more soldiers?" I asked Amer. "Well, yes, of course," he explained, "but it's also to keep families from taking advantage of the system . . . everyone will want to put all their sons into university to keep them from going to the army."

The war has also changed the length of military service from a fixed number of months to a period that could have no definite end. Soldiers serving since 2010, known as Dowra 102 (Recruitment Class 102), have been the subject of much discussion among Syrians. The reality that one would have to go and fight for years and years, perhaps indefinitely, two men told me during one conversation, has served as further motivation to evade conscription through labor migration or other means. At the end of May 2018, the Dowra 102 were finally deactivated and allowed to return home. ${ }^{7}$

While officially the definition of military age remains eighteen to forty-two, there have been reports of men as old as fifty directed to register for reserve duty and boys under the age of eighteen conscripted (Danish Immigration Service 2015; UNHCR 2017). Several presidential decrees offering amnesty for defectors have been issued since the war began, declaring that those who have evaded conscription and fled to locations both within and outside the country will only be required to complete their military service but not face punishment (see, e.g., Al-Khalidi 2015). People do not rely on such decrees and announcements, Walid, a civil service employee, told me. He had moved to work in Doha after his salary no longer provided an adequate livelihood because of wartime inflation (Abdulrahim 2017). "There are rules that can be in place or there is a policy issued about something, but you can't be sure that that's what will actually happen.” In fact, I was told that although the news media report policy changes concerning military service, people hear about them, as they do about other aspects of the war, through Facebook or word of mouth (Dagher 2018). ${ }^{8}$

Significant insecurity exists, then, even for those men who might technically be exempt from service. Hamid related one such story that concerned someone from a village near his. He told me of a man who had been regularly filing the yearly document (sanat iqama) that designated his status as a worker abroad and was paying off the military-exemption fee within a five-year period. This man suffered an accident while working in the UAE. Thinking he was safe from conscription and unable to work, he returned home - only to be seized at the airport in 
Damascus because his exemption document had not yet received official approval. He was later killed fighting. "You see," Hamid explained, "you can send your paperwork back to Syria for approval, but you cannot be sure how long that will take, so even if you are set up in the system to pay off your service because you are working outside Syria, if your paperwork has not been approved, they can still take you." To avoid this stress and uncertainty, some workers in Doha bear significant costs to travel to Oman - the nearest accessible Syrian embassy since the one in Qatar closed in 2011 — to file their documents and wait until they are approved. But few can afford to do this because of travel costs and the time off from work it requires. As Hamid put it, "you might go to Oman and wait for weeks for the approval; there is no way you can know how long it will take.”

Checkpoints, where forced recruitment even for protected populations has been known to take place, are feared. Basel, who worked in Lebanon before coming to Qatar in 2010, was the first to describe to me the udrub fiche - the computerized registry that holds information about one's military status. "I visited Syria without worrying for a couple of years, during the first years of the war, because I had done my military service in the late 1990s, but then they were running out of manpower, so when I went back in 2016, it was a different story." At one checkpoint on the way to his hometown, Basel handed over his ID to a soldier. The soldier returned and said his name was flagged, that at age forty-one, he was still within the age limits. Basel paid a bribe — he remembered paying about US\$10 or US\$20 - to be let through, and he did the same on his way out of Syria, heading to Lebanon for his flight. But on the return trip he paid off the solider straightaway before even handing him his ID, just in case someone at the checkpoint was in possession of the computerized database.

The violent threat of wartime conscription and its bureaucratic order materialize in the state space of the checkpoint and its instrument, the fiche. To come and go during the war entails confrontation with this threat. But the regime of forced conscription during the long war in Syria has gone beyond the bounds of the nation. The risk of conscription has become not just a cause for leaving Syria but an ongoing threat exerted across a global landscape. And, while facing this risk, many men labor in the Arab Gulf, trading military service for another form of enlistment.

\section{MASCULINE TRAJECTORIES}

In a 2018 propaganda video, "Braids of Fire" (RT News Arabic 2018), aimed at the young men of Syria, Asma Assad, the wife of the Syrian president, speaks to a 
group of female army volunteers in a disparaging tone about the "so-called men" who have fled and hid to escape their soldierly duty. "You are the ones on the front lines," she says to the women, you are "tougher [islab, literally, more steel-like] than they are." In her denigration of the man who does not fight, Assad invokes the "logic of militarism and masculine protection" central to the construction of Syrian national identity (Aldoughli 2018), but she also misses the point made by the men I spoke with in Doha: that only by not being soldiers and leaving Syria for lives as laborers in the Gulf can they fulfill the role of masculine protector of their own families. Unlike the Palestinian men in the Israeli army whom Rhoda Ann Kanaaneh (2008, 83-84) describes as receiving regular paychecks and myriad public and educational benefits that help make them providers for their families, the Syrian wartime soldier, even if he is not injured or killed, cannot support his. With monthly compensation of about US\$50 per month (Westall and Al-Khalidi 2015), conscription means an inability to provide.

All the men I spoke with regularly send remittances to Syria, generally via cash-transfer offices in Lebanon, where money can be picked up by a friend or relative and given to a cross-border taxi driver charged with its delivery. But the amount of money that goes home is reduced because of the need to save for the payment of the exemption fees. As Amer described, "I paid the US\$8,000 already, I borrowed from people, so now I'm working to pay this off. I think about it, about how much this is, I mean . . . I could have bought a house in my village for this amount." The exemption-fee structure that has allowed men to avoid military service during wartime is experienced as a form of extortion. And while payment of the fees ensures access to Syria, to home and family, the siphoning of earnings means the deferral of certain life-course transitions. The costs of marriage and setting up a home, for instance, are instead paid out to the state. For Basel, who is in his early forties, the decision to stay and work as a waiter in Doha is marked by the delay of the experience of fatherhood. It is during his time in Qatar, after working in both Damascus and Lebanon as a chef, that both of his sons have been born. "Honestly, for me, I feel like with this money I send home to them [to my wife and young sons], I am just replacing myself. But my children need their father." With this notion of replacing himself through remittances that both stand in for and also create emotional and material connectedness with his family (Ghannam 1998), Basel spoke to the different ways in which the exemption fees constitute badal (substitutes), as they are referred to in Arabic: instead of getting a soldier to fight its war, the state receives money; instead of a father facing the mortal risk of fighting a war, his children have an absent one. 
With women remaining at home to do physical care work on the home front for children, younger siblings, and aging parents (Coe 2016), the men I met clearly provided care through remittances, but also other forms of nurturing. Rami, for example, says that through both texts and especially recorded voice messages on WhatsApp, his family consults him on every decision, that they "keep him connected" (Ghannam 1998) and that he not only has to "pay for them," he has to "think for them." Men with younger brothers spoke of how the threat of conscription raises the stakes of their roles as (male) protectors by sending money for tuition fees to delay their military service. Mazen related how two of his brothers working in Doha avoided going back to Syria by finding their way to Panama and later Ecuador, where they could enter with still-valid Qatari residence permits. But once in Ecuador, the brothers kept requesting that he send money to help them set up a restaurant. "They are safe, they're not in Syria, but now I'm trapped here working" — even after paying off his own conscription_- "so that I can keep sending them money. I keep saying that I'll finish my time here soon, I keep setting deadlines. We all do this, we say 'oh, when my trip home comes next year, then I'm not coming back.' But we don't know when we'll get out."

Economic migration has long been a feature of Syrian society, but the out-migration induced by the war no longer represents or constitutes, as it had, a pathway for upward mobility. Several of the men I spoke with, including Rami, with whose words I began this article, have college educations in fields like art, engineering, and banking. Prior to the war, they might have come to the Gulf to work in the fields in which they were trained. But lack of diplomatic relations between the Syrian regime and the Gulf states - the Syrian opposition opened its own embassy in Qatar in 2013 — has made it increasingly difficult to obtain work and family visas. Many of the men I spoke to work for one of the numerous holdings of a Syrian billionaire who has, because of his clout, continued to hire Syrians throughout the war. Thus the aspirations that transnational migration often allows for, that it involves an eventual move up that helps one build a better future for oneself and one's kin, have been upset by the war. Other men never imagined migrating for work. Though now laboring abroad as a bank employee, Walid had not considered leaving during the early years of the war. In Syria, he was a civil service employee working as an accountant with a stable salary, state-provided benefits (such as no-interest loans for new appliances), and long-term job security. But wartime inflation began to push prices so high, even for basic goods, that he found it impossible to provide for his family. "This banana," he gestured to the fruit assem- 
bled on the table in front of us, "you would not believe it . . . a banana became this very special luxury, I would bring one home to my children perhaps once a week.”

The war has upset other life-course trajectories as well. Mazen, a forty-fiveyear old, had worked for the same Doha restaurant for eleven years when he and his brother were summarily fired for budgetary reasons in early 2018. In 2010 he had returned to Syria to get married. After a subsequent visit in 2012, when he paid a bribe after his name was found in the registry of those due for military service, he felt the risk of returning was too great and remained in Doha. His wife gave him an ultimatum at one point because she was so frustrated by trying to build a marriage without him present; they divorced in 2015. Two years later, his ailing father passed away. His younger brother, who had paid off his military exemption, returned for the burial, but Mazen still felt he could not take the risk. He missed saying goodbye to his father. Youssef, a restaurant worker who has not yet paid the US\$8,000 exemption fee and has not returned to Syria for seven years, has given up on the idea that he will marry a Syrian woman. "How will I meet her and get to know her?" he asked rhetorically. "My brother in Saudi, he can't return either, so he became engaged by Skype. Our mom had them meet, they courted by Skype ... and then she came to Saudi for umrah [the "minor" pilgrimage to Mecca, which a Muslim can perform anytime of the year] and they got married. My mom came too, and I was able to meet them there.” But Qatar is not like Saudi, he explained; it is not feasible to imagine a Syrian woman getting a family visa to come and live with him. The challenge of imagining a life deferred — of getting married to and having a family with a Syrian woman-became too much:

I have a girlfriend now from Indonesia, we met online, we have been together for a couple of years. I hope that we will get married. My parents don't approve, but I have to live! Life here is so hard, it's only work. . . . After so many years, I needed to get a car, a girlfriend, you have to feel like you are living. Like you have something.

For the Syrian men I met, the war shaped masculine trajectories in various ways. While the role of financial provider can largely be fulfilled through transnational labor migration, the insecurities of war have unsettled the path to realizing other socially recognized masculine roles and norms. In her research with Syrian men living as refugees in Egypt, Magdalena Suerbaum (2017) found that in displacement, the transition into adulthood for young men proved incomplete and partial, and that the challenges of achieving the middle-class norms of Syrian male 
respectability, having to do not just with providing but also with consuming (Suerbaum 2018b, 680), have disrupted both their passages into manhood and their own notions of masculinity. Similarly, for Syrian men avoiding conscription in Doha, displacement from home has created empty spaces in their life trajectories, ones marked by non-participation in rituals of marriage, fatherhood, and death. Weary from imagining a life deferred, Youssef has begun to fill in these spaces and cultivate a life in which, to use his words, he has something.

While a sacrificial economy (Weiss 2014) surely characterizes the regime of conscription for Syrian soldiers on the front lines of the conflict who risk their lives for the state, a different sort of sacrifice defines the experience of avoiding the war through the payment of exemption fees. The risks of fighting are substituted for a life put on a long pause with no clear or self-selected end. This is a life of work with little autonomy and plans for a future that feels at once overdue but always postponed. These are, of course, the life conditions of the majority of Qatar's migrant laborers in the kefala system. But Syrians labor not only under the threat of losing their jobs and of not being able to earn to provide but also with the threat of being sent back to wartime Syria. This is a specific vulnerability shared by military-age Syrian men across the warscape, as Suerbaum (2018a, 369) also relates about the fears of Syrian refugees in Egypt. Mazen, for instance, told me of how he and a coworker approached the restaurant management to request a reduction in the number of employees per room in their employer-provided housing: "We weren't just told 'no'; we were told, 'go back to Syria if you don't like it.' They know we are all afraid of going back, that we have to stay outside Syria. They use this." The threat of conscription organizes life for military-age Syrian men at home, and also for those away. The Syrian state, in this way, extends out beyond the boundaries of the nation. Mazen, after telling his story about talking to his boss, continued, "You want to know what the war means for us? That's what you said you wanted to hear about, right? We curse that we are Syrian. That's all we can do.”

\section{CONCLUDING THOUGHTS}

Hassan al-Kontar, a Syrian man in his late thirties, lived in the Kuala Lumpur airport for more than seven months. Deported from the UAE, where he had lived illegally since 2011 when his work visa expired to avoid returning to Syria, where he faced immediate conscription, he made the Malaysian airport his refuge after being turned away from a flight to Ecuador, where he had hoped to gain entry. From the plight of al-Kontar, widely covered in Western news media and through 
social media campaigns, and his plaintive assertion that the war in Syria is "not my war" (Ahmed 2018), emerged a lesser-known narrative of the Syrian conflict and of the social impact of war more broadly: the gendered experiences of military-age men. During the Syrian conflict, the performance of manhood has been both dislocated (Cornwall and Lindisfarne 2016) by, for example, the avoidance of military duty and refugee status under humanitarian care (Turner 2019) and, at the same time, sustained through the labor migrations that enable men to maintain their role as providers.

In my analysis of the lives and experiences of a group of Syrian men in Qatar, I have shown how conscription in Syria operates as a form of debt exchange. Through the years-long payment of exorbitant exemption fees that diminish remittances sent to families but should allow access to home, these migrant laborers avoid military service but remain indentured to the state. Moreover, while the rites of male adulthood are delayed, or displaced to younger brothers, and absence from kin is endured, they lead half-lived lives as contract laborers with little autonomy in the Gulf's kefala system, with the constant threat of being returned to Syria hanging over their heads. In this wartime economy of sacrifice, one form of conscription comes to be exchanged for another.

Across two authoritarian regimes during the Syrian conflict, we see how the state's patriarchal bargain is not destabilized but instead reframed. The extraction of the military labor on which the terms of Syrian male citizenship are founded is converted into U.S. dollars earned by joining the global capitalist workforce. Unchanged in this reframing is the insistence that men provide for and protect their families. As a consequence of how the male body is constituted as physical capital that must remain subordinate to both patriarchal and capitalistic demands (Ghannam 2013, 170), men's breadwinner status in the Syrian context, and more broadly throughout the region, produces a new set of gendered vulnerabilities. In times of conflict and instability, these demands send men out and away from their families and communities, but also dislocate them from the life course itself. In fulfilling their end of the bargain through political obedience and economic production, they miss out on a particular stage of manhood and the aspirations, projects, and affective promises it holds.

\section{ABSTRACT}

In this essay, I provide a different perspective on the Syrian conflict by examining how the war's reach can also be located amid the losses, interruptions, and experiences of those Syrians who have until now largely escaped its incredible violence. By 
looking closely at how the war has altered the life trajectories of and produced distinct modes of vulnerability for military-age men, I develop an argument about how, although they avoid fighting by going to work in Qatar, the lives of a group of Syrian men remain defined by conscription. Through my investigation of how these men are located in a landscape of conscription that extends beyond the borders of Syria, I build on anthropological knowledge of how masculinity is shaped by and through contexts of political destabilization. I demonstrate how, in fulfilling their end of the patriarchal bargain through political obedience and economic production, these men lose a particular stage of manhood and the aspirations, projects, and affective promises it holds. [masculinity; conscription; war; labor; migration; Syria]

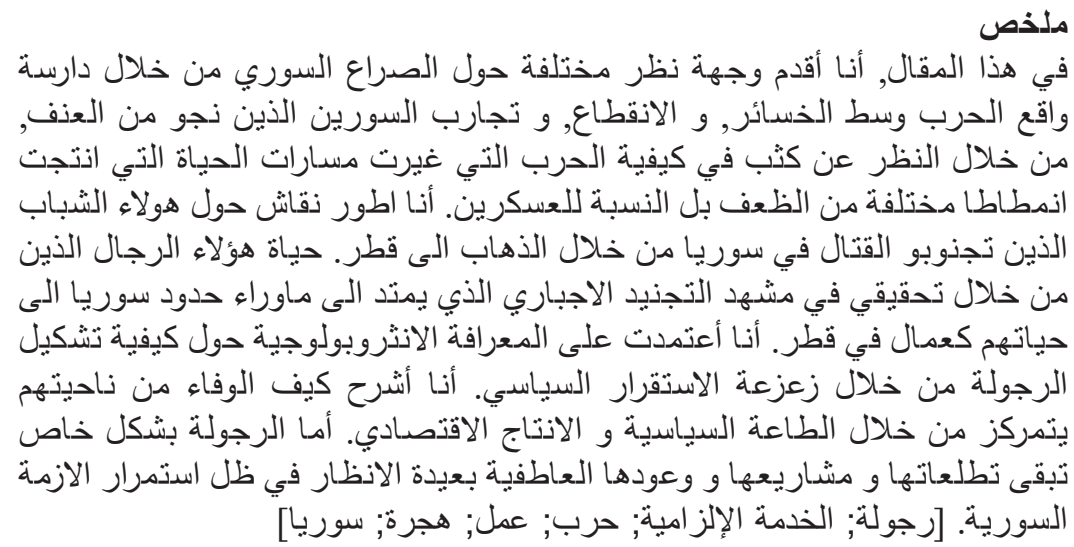

\section{NOTES}

Acknowledgments I am indebted to the men in Doha who gave of their time and shared their stories. The ideas presented here were enriched by feedback from Sami Hermez, Giulia El Dardiry, Wendy Pearlman, and other participants in the September 2018 "(In)Security in Everyday Life" workshop in Beirut supported by the Arab Council for Social Sciences and the Wenner-Gren Foundation. Earlier versions of this essay benefited tremendously from the suggestions made by my colleagues Erin Koch, Sarah Lyon, and Karen Rignall, as well as the careful and generous reading of three anonymous reviewers. The editors of Cultural Anthropology, especially Heather Paxson, provided valuable guidance and sharp insights.

1. This is a lowly service position at restaurants involving the setup of water tobacco pipes and continuous checking to ensure that the hot coals that fuel them are refreshed.

2. The GCC is a political and economic coalition of six Gulf countries - Saudi Arabia, Kuwait, the United Arab Emirates, Qatar, Bahrain, and Oman. The coalition has been strained recently by rising political tensions between Qatar and Saudi Arabia, which resulted in an air, sea, and land embargo of Qatar, led by Saudi Arabia, and the severing of diplomatic relations between Qatar and several GCC countries. The rift began in June 2017 and is ongoing at the time of this writing.

3. See, for example, Gulf Labour Markets and Migration (GLMM) Programme (2017).

4. I use a simplified system for transliterating Arabic, omitting all indication of long versus short vowels, as well as any distinctions between hard and soft letters. I trust that specialist readers will be able to use the context to follow my transliteration. 
5. Massacres and the kidnapping of women from Druze villages by ISIS-affiliated militias in July 2018 renewed this friction (Maksad 2018).

6. The workers I spoke with earned between US\$750 and US\$2,000 per month.

7. Views differ about the decision to release them. Some say it was influenced by the Facebook-generated outcry (Syria Direct 2015), whereas a pro-regime news agency cites recent military gains as the cause (Aboufadel 2018).

8. One man changed his route from Syria after learning through Facebook of the dangerous weather conditions along his planned route through Lebanon (Dagher 2018).

\section{REFERENCES}

Abdulrahim, Raja

2017 "War-Torn Syria's Battered Economy Marked by Inflation and Poverty: Nation's GDP Has Dropped by More Than Half This Decade; 'A Pretty Nightmarish' Situation.” Wall Street Journal, July 28. https://www.wsj.com/articles/war-tornAboufadel, Leith syrias-battered-economy-marked-by-inflation-and-poverty-1501234205.

2018 “Syrian Army Allows Soldiers Serving since 2010 to Return Home." Al-Masdar News, May 26. https://www.almasdarnews.com/article/syrian-army-allowssoldiers-serving-since-2010-to-return-home/.

Abu-Lughod, Lila

1988 "Fieldwork of a Dutiful Daughter." In Arab Women in the Field: Studying Your Own Society, edited by Soraya Altorki and Camillia Fawzi El-Solh, 139-61. Syracuse: Aciksoz, Salih Can Syracuse University Press.

2017 "He Is a Lynched Soldier Now: Coup, Militarism, and Masculinity in Turkey." Journal of Middle East Women's Studies 13, no. 1: 178-80. https://doi. Ahmad, Attiya org/10.1215/15525864-3728811.

2017 Everyday Conversions: Islam, Domestic Work, and South Asian Migrant Women in Kuwait. Durham, N.C.: Duke University Press.

Ahmed, Kaamil

2018 “It's not my war': The Syrian Man Who Has Spent a Month Living in Kuala Lumpur Airport." Guardian (UK), April 11. https://www.theguardian.com/ world/2018/apr/12/its-not-my-war-the-syrian-man-who-has-spent-a-month-

Aldoughli, Rahaf living-in-kuala-lumpur-airport.

2018 "Belonging to a Militarized Syria as a Woman." Syria Untold, January 5. https:// Al-Jablawi, Hosam syriauntold.com/2018/01/05/belonging-to-a-militarized-syria-as-a-woman/.

2019 "Forced Conscription Continues despite Amnesty by Syrian Government." Atlantic Council website, February 13. https://www.atlanticcouncil.org/ blogs/syriasource/forced-conscription-continues-despite-amnesty-by-syrian-

Al-Khalidi, Suleiman government/.

2015 “Syria's Assad's Announces Amnesty for Army Deserters: Syrian TV." Reuters, July 25. https://www.reuters.com/article/uk-mideast-crisis-army/syrias-assadsannounces-amnesty-for-army-deserters-syrian-tv-idUSKCNOPZ07K20150725.

Al-Monitor

2017 “Qatar Population Booms on Back of 2022 World Cup." Al-Monitor, March 2. https://www.al-monitor.com/pulse/afp/2017/03/fbl-qatar-population-laboutwc-2022.html.

Allsopp, Jennifer

2017 "Aggressor, Victim, Soldier, Dad: Intersecting Masculinities in the European 'Refugee Crisis." In A Gendered Approach to the Syrian Refugee Crisis, edited by Jane 
Altinay, Ayșe Gül

Freedman, Zeynep Kivilcim, and Nurcan Özgür Baklacığlu, 155-74. London: Routledge.

2004 The Myth of the Military Nation: Militarism, Gender, and Education in Turkey. New York: Palgrave Macmillan.

Baban, Feyzi, Suzan Ilcan, and Kim Rygiel

2017 "Syrian Refugees in Turkey: Pathways to Precarity, Differential Inclusion, and Negotiated Citizenship Rights." Journal of Ethnic and Migration Studies 43, no. 1: 41-57. https://doi.org/10.1080/1369183X.2016.1192996.

Babar, Zahra, and Andrew Gardner

2016 “Circular Migration and the Gulf States." In Impact of Circular Migration on Human, Political and Civil Rights, edited by Carlota Solé, Sonia Parella, Teresa Sordé Martí, and Sonja Nita, 45-62. Cham, Switzerland: Springer.

Canessa, Andrew

2012 Intimate Indigeneities: Race, Sex, and History in the Small Spaces of Andean Life. Durham, N.C.: Duke University Press.

Coe, Cati

2016 "Orchestrating Care in Time: Ghanaian Migrant Women, Family, and Reciprocity." American Anthropologist 118, no. 1: 37-48. https://doi.org/10.1111/aman.12446.

Cornwall, Andrea, and Nancy Lindisfarne

2016 "Dislocating Masculinity: Gender, Power and Anthropology." In Dislocating Masculinity: Comparative Ethnographies, 2nd ed., edited by Andrea Cornwall and Nancy Lindisfarne, 27-61. Abingdon, UK: Routledge.

Dagher, Sam

2018 "Assad Is Desperate for Soldiers: The Problem Is that Few Want to Fight for Him." Atlantic, May 14. http://www.theatlantic.com/international/archive/2018/05/ syria-Asad-conscription-refugees-lebanon/560282/?utm_source $=\mathrm{eb}$.

Danish Immigration Service

2015 Syria: Update on Military Service, Mandatory Self-Defence Duty and Recruitment to the YPG. Copenhagen: Danish Immigration Service. https://www.refworld.org/ docid/5629d2584.html.

Davis, Rochelle

2016 "Gendered Vulnerability and Forced Conscription in the War in Syria." In The Long-Term Challenges of Forced Migration: Perspectives from Lebanon, Jordan and Iraq, LSE Middle East Centre Collected Papers Volume 6, September 2016, 49-54.

Davis, Rochelle, Abbie Taylor, and Emma Murphy

2014 "Gender, Conscription and Protection, and the War in Syria." Forced Migration Review 47: 35-38. https://www.fmreview.org/syria/davis-taylor-murphy.

De Bel-Air, Françoise

2015 "A Note on Syrian Refugees in the Gulf: Attempting to Assess Data and Policies." GLMM-EN-No. 11/2015, Gulf Research Centre, European University Institute. http://hdl.handle.net/1814/37965.

De Châtel, Francesca

2014 "The Role of Drought and Climate Change in the Syrian Uprising: Untangling the Triggers of the Revolution.” Middle Eastern Studies 50, no. 4: 521-35. https://doi. Gardner, Andrew M. org/10.1080/00263206.2013.850076.

2010 City of Strangers: Gulf Migration and the Indian Community in Bahrain. Ithaca, N.Y.: Cornell University Press.

2018 "Reflections on the Role of Law in the Gulf Migration System." Journal of Legal Studies 47, supp. 1: S129-S147. https://doi.org/10.1086/693436.

Gardner, Andrew, Silvia Pessoa, Abdoulaye Diop, Kaltham Al-Ghanim, Kien Le Trung, and

Laura Harkness

2013 "A Portrait of Low-Income Migrants in Contemporary Qatar." Journal of Arabian Studies 3, no. 1: 1-17. https://doi.org/10.1080/21534764.2013.806076. 
Ghannam, Farha

1998 "Keeping Him Connected: Labor Migration and the Production of Locality in Cairo.” City and Society 10, no. 1: 65-82. https://doi.org/10.1525/city.1998.10.1.65.

2013 Live and Die Like a Man: Gender Dynamics in Urban Egypt. Stanford, Calif.: Stanford University Press.

Gill, Lesley

1997 "Creating Citizens, Making Men: The Military and Masculinity in Bolivia." Cultural Anthropology 12, no. 4: 527-50. https://doi.org/10.1525/can.1997.12.4.527.

Gulf Labour Markets and Migration (GLMM) Programme

2017 "Percentage of Nationals and Foreign Nationals in GCC Countries' Populations (Latest Year Available, 2010-2016)." https://gulfmigration.org/media/graphs/

Hafez, Sherine Graph1_09_05_2017.pdf.

2012 "No Longer a Bargain: Women, Masculinity, and the Egyptian Uprising." American Ethnologist 39, no. 1: 37-42. https://doi.org/10.1111/j.1548-1425.2011.01344.x.

Hall, Stuart

1985 "Signification, Representation, Ideology: Althusser and the Post-structuralist Debates." Critical Studies in Mass Communication 2, no. 2: 91-114. https://doi. org/10.1080/15295038509360070.

ILO (International Labour Organization)

n.d. "Qatar." Accessed March 4, 2020. https://www.ilo.org/beirut/countries/qatar/ WCMS_654238/lang--en/index.htm.

Immigration and Refugee Board of Canada

2014 "Syria: Compulsory Military Service, Including Age of Recruitment, Length of Service; Occasions Where Proof of Military Service Status Is Required; Whether the Government Can Recall Individuals Who Have Already Completed Their Compulsory Military Service; Penalties for Evasion (2008-July 2014)." Document SYR104921.E. https://www.refworld.org/docid/54042353a.html.

2017 "Syria: Changes to Legal Exemptions from Compulsory Military Service, Including Implementation (January-July 2017).” Document SYR105971.E. https://www.

Jamal, Manal A. refworld.org/docid/59d37c754.html.

2015 "The 'Tiering' of Citizenship and Residency and the 'Hierarchization' of Migrant Communities: The United Arab Emirates in Historical Context." International Migration Review 49, no. 3: 601-32. https://doi.org/10.1111\%2Fimre.12132.

Jureidini, Ray

2014 “Arab Gulf States: Recruitment of Asian Workers.” Technical Report, GLMM, Explanatory note 3/2014, European University Institute and Gulf Research Centre. http://hdl.handle.net/1814/32149.

Kanaaneh, Rhoda Ann

2008 Surrounded: Palestinian Soldiers in the Israeli Military. Stanford, Calif.: Stanford University Press.

Kandiyoti, Deniz

1988 "Bargaining with Patriarchy." Gender and Society 2, no. 3: 274-90. https://doi.org/ 10.1177\%2F089124388002003004.

Khaddour, Kheder

2016 "Strength in Weakness: The Syrian Army's Accidental Resilience." Carnegie Middle East Center website, March 14. https://carnegie-mec.org/2016/03/14/ Khatri, Shabina strength-in-weakness-syrian-army-s-accidental-resilience-pub-62968.

2017 "Most of Qatar's Residents Come from These Six Countries." Doha News, February 12. https://medium.com/dohanews/most-of-qatars-residents-come-from-thesesix-countries-17ba633ccb2f. 
Khlebnikov, Alexey

2018 "Evolution of the Syrian Military: Main Trends and Challenges." Russian International Affairs Council website, November 19. https://russiancouncil.ru/ en/analytics-and-comments/analytics/evolution-of-the-syrian-military-maintrends-and-challenges/.

Koehler, Kevin, Dorothy Ohl, and Holger Albrecht

2016 "From Disaffection to Desertion: How Networks Facilitate Military Insubordination in Civil Conflict." Comparative Politics 48, no. 4: 439-57. https://

Leonard, Karen www.jstor.org/stable/24886182.

2003 "South Asian Workers in the Gulf: Jockeying for Places." In Globalization under Construction: Governmentality, Law, and Identity, edited by Richard Warren Perry and Bill Maurer, 129-70. Minneapolis: University of Minnesota Press.

Lubkemann, Stephen C.

2008 Culture in Chaos: An Anthropology of the Social Condition in War. Chicago: University of Chicago Press.

Lynch, Marc

2018 “The New Arab Order: Power and Violence in Today's Middle East.” Foreign Affairs 97: 116-26. https://www.foreignaffairs.com/articles/middle-east/2018-08-13/ new-arab-order.

Maadad, Nina, and Grant Rodwell

2016 Schooling and Education in Lebanon: Syrian and Syrian Palestinian Refugees Inside and Outside the Camps. Bern: Peter Lang.

Mahdavi, Pardis

2011 Gridlock: Labor, Migration, and Human Trafficking in Dubai. Stanford, Calif.: Stanford University Press.

Maksad, Firas

2018 "The Tragedy that Befell the Druze in Syria Is a Stark Reminder of Their Solo Battle for Survival.” National, July 30. https://www.thenational.ae/opinion/ comment/the-tragedy-that-befell-the-druze-in-syria-is-stark-reminder-of-theirsolo-battle-for-survival-1.755483.

Naguib, Nefissa

2017 "Middle East Encounters 69 Degrees North Latitude: Syrian Refugees and Everyday Humanitarianism in the Arctic." International Journal of Middle East Studies 49, no. 4: 645-60. https://doi.org/10.1017/S0020743817000630.

Nagy, Sharon

1998 “'This Time I Think I'll Try a Filipina': Global and Local Influences on Relations between Foreign Household Workers and Their Employers in Doha, Qatar." City Narayan, Kirin

and Society 10, no. 1: 83-103. https://doi.org/10.1525/city.1998.10.1.83.

1993 "How Native is a 'Native' Anthropologist?" American Anthropologist 95, no. 3: 671Naylor, Hugh 86. https://doi.org/10.1525/aa.1993.95.3.02a00070.

2015 “In a New Sign of Assad's Troubles, Syria’s Druze Turn Away from President." Washington Post, July 20. https://www.washingtonpost.com/world/ middle_east/in-new-sign-of-assads-troubles-syrias-druze-turn-away-from-

Nordstrom, Carolyn president/2015/07/17/eaf06874-18f7-11e5-bed8-1093ee58dad0_story.html.

1997 A Different Kind of War Story. Philadelphia: University of Pennsylvania Press.

Pankhurst, Donna

2008 "Post-War Backlash Violence against Women: What Can 'Masculinity' Explain?" In Gendered Peace: Women's Struggles for Post-War Justice and Reconciliation, edited by Donna Pankhurst, 293-320. New York: Routledge. 
Pearlman, Wendy

2016 "Narratives of Fear in Syria." Perspectives on Politics 14, no. 1: 21-37. https://doi. org/10.1017/S1537592715003205.

2017 We Crossed a Bridge and It Trembled: Voices from Syria. New York: HarperCollins. Phillips, Christopher

2016 The Battle for Syria: International Rivalry in the New Middle East. New Haven, Conn.: Yale University Press.

RT News Arabic

2018 "Asma Al-Assad Announces 'Braids of Fire.” RT News Arabic, March 22. https:// arabic.rt.com/middle_east/933726-\%D8\%A3\%D8\%B3\%D9\%85\%D8\%A7\%D8 \%A1-\%D8\%A7\%D9\%84\%D8\%A3\%D8\%B3\%D8\%AF-0D8\%AA\%D8\%AE \%D8\%A7\%D8\%B7\%D8\%A8-\%D8\%B6\%D9\%81\%D8\%A7\%D8\%A6\%D8\%B1$\% \mathrm{D} 8 \% \mathrm{~A} 7 \% \mathrm{D} 9 \% 84 \% \mathrm{D} 9 \% 86 \% \mathrm{D} 8 \% \mathrm{~A} 7 \% \mathrm{D} 8 \% \mathrm{~B} 1 /$.

Specia, Megan

2018 "How Syria's Death Toll Is Lost in the Fog of War. New York Times, April 13. https:// www.nytimes.com/2018/04/13/world/middleeast/syria-death-toll.html.

Suerbaum, Magdalena

2017 "What Does It Mean to Be Young for Syrian Men Living as Refugees in Cairo?" Middle East Topics and Arguments 9: 122-31. https://doi.org/10.17192/ meta.2017.9.6838.

2018a "Becoming and 'Unbecoming' Refugees: Making Sense of Masculinity and Refugeness among Syrian Refugee Men in Egypt.” Men and Masculinities 21, no. 3: 363-82. https://doi.org/10.1177\%2F1097184X17748170.

2018b "Defining the Other to Masculinize Oneself: Syrian Men's Negotiations of Masculinity during Displacement in Egypt.” Signs 43, no. 3: 665-86. https://doi. org/10.1086/695303.

Syria Direct

2015 "Regime Supporters Demand End to Years-Long Mandatory Military Service." Syria Direct, January 12. https://syriadirect.org/news/regime-supportersdemand-end-to-years-long-mandatory-military-service/.

Syrian Embassy in Australia

n.d. "Obtain a Syrian Citizenship.” Dual citizenship form. Accessed March 4, 2020. http://www.syrianembassy.com.au/forms/english_forms/Dual_Citizenship_

Thomas, Todne en.pdf.

2016 "Strangers, Friends, and Kin: Negotiated Recognition in Ethnographic Relationships." Anthropology and Humanism 41, no. 1: 66-85. https://doi. Turner, Lewis $\operatorname{org} / 10.1111 / \mathrm{anhu} .12108$.

2017 "Who Will Resettle Single Syrian Men?" Forced Migration Review 54: 29-31. https://www.fmreview.org/resettlement/turner.

2019 "Syrian Refugee Men as Objects of Humanitarian Care." International Feminist Journal of Politics 21, no. 4: 595-616. https://doi.org/10.1080/14616742.2019.164 1127.

UNHCR (UN High Commissioner for Refugees)

2017 "Relevant Country of Origin Information to Assist with the Application of UNHCR's Country Guidance on Syria: 'Illegal Exit' from Syria and Related Issues for Determining the International Protection Needs of Asylum-Seekers from Syria." https://www.refworld.org/docid/58da824d4.html.

Valenta, Marko, and Jo Jakobsen

2016 "Moving to the Gulf: An Empirical Analysis of the Patterns and Drivers of Migration to the GCC Countries, 1960-2013." Labor History 57, no. 5: 627-48. https://doi.org/10.1080/0023656X.2016.1239885. 
2017 "Mixed Migrations to the Gulf: An Empirical Analysis of Migrations from Unstable and Refugee-Producing Countries to the GCC, 1960-2015.” Refugee

Vora, Neha Survey Quarterly 36, no. 2: 33-56. https://doi.org/10.1093/rsq/hdx002.

2013 Impossible Citizens: Dubai's Indian Diaspora. Durham, N.C.: Duke University Press.

2018 Teach for Arabia: American Universities, Liberalism, and Transnational Qatar. Stanford, Calif.: Stanford University Press.

Vora, Neha, and Natalie Koch

2015 "Everyday Inclusions: Rethinking Ethnocracy, Kafala, and Belonging in the Arabian Peninsula." Studies in Ethnicity and Nationalism 15, no. 3: 540-52. https://

Wedeen, Lisa doi.org/10.1111/sena.12158.

2013 "Ideology and Humor in Dark Times: Notes from Syria." Critical Inquiry 39, no. 4: 841-73. https://doi.org/10.1086/671358.

Weiss, Erica

2014 Conscientious Objectors in Israel: Citizenship, Sacrifice, Trials of Fealty. Philadelphia: University of Pennsylvania Press.

Westall, Sylvia, and Suleiman Al-Khalidi

2015 "Syria to Hike Pay of Frontline Soldiers with Bonus: PM.” Reuters, June 8. https:// www.reuters.com/article/us-mideast-crisis-syria-military/syria-to-hike-pay-offrontline-soldiers-with-bonus-pm-idUSKBNOOO1IR20150608. 